\title{
The assassination of Robert F. Kennedy: an analysis of the senator's injuries and neurosurgical care
}

\author{
Jordan M. Komisarow, MD, ${ }^{1}$ Theodore Pappas, MD, ${ }^{2}$ Megan Llewellyn, MSMI, ${ }^{2}$ and \\ Shivanand P. Lad, MD, PhD' ${ }^{1}$ \\ Departments of ${ }^{1}$ Neurosurgery and ${ }^{2}$ Surgery, Duke University School of Medicine, Durham, North Carolina
}

\begin{abstract}
On June 5, 1968, having won the Democratic Party presidential primary in California, Senator Robert F. Kennedy delivered a victory speech to supporters at the Ambassador Hotel in downtown Los Angeles. Just after 12:15 Am (Pacific daylight savings time), a lone assassin shot Kennedy 3 times at point-blank range. One of the bullets struck Kennedy in the right posterior auricular region. Within the ensuing 26 hours, Kennedy was transported to 2 hospitals, underwent emergency surgery, and eventually died of severe brain injury. Although this story has been repeated in the press and recounted in numerous books, this is the first analysis of the senator's injuries and subsequent surgical care to be reported in the medical literature. The authors review eyewitness reports on the mechanism of injury, the care rendered for 3 hours prior to the emergency craniotomy, the clinical course, and, ultimately, the autopsy.

https://thejns.org/doi/abs/10.3171/2018.4.JNS18294
\end{abstract}

KEYWORDS Robert F. Kennedy; assassination; traumatic brain injury; history

$I^{\prime}$ N June 1968, the United States presidential campaign was in full swing. The leading Republican candidate, Richard Nixon, was challenged for the nomination by 3 Republican governors: George Romney of Michigan, Nelson Rockefeller of New York, and Ronald Reagan of California. Nixon eventually won the Republican Party nomination. ${ }^{11}$ After President Lyndon B. Johnson announced that he would not run for reelection on March $31{ }^{41}$ Senators Robert F. Kennedy of New York and Eugene McCarthy of Minnesota became the leading Democratic candidates in states holding presidential primaries. Hubert H. Humphrey, the Democratic incumbent vice president, campaigned mostly in states that did not hold primaries. Coming into the California primary, the Kennedy campaign felt that a win was essential for their candidate to keep up with McCarthy and move into the August 26 Democratic National Convention with a chance of beating Humphrey, who was leading in committed delegates. ${ }^{12}$

\section{The Assassination}

Upon winning the California presidential primary, Senator Kennedy addressed his supporters just after midnight on the morning of June 5 in the Embassy Ballroom of the Ambassador Hotel in the Wilshire district of downtown
Los Angeles. In 1968, Secret Service personnel were not routinely deployed to protect presidential candidates; ${ }^{39}$ however, Kennedy did have a small security detail, headed by a former Federal Bureau of Investigation agent, William Barry. Other members of this "security team" included former National Football League lineman Rosey Grier and former Olympic gold medalist Rafer Johnson. ${ }^{26}$ After Senator Kennedy spoke, the plan was for the candidate to walk through the hotel kitchen to the Colonial Room, where members of the press were waiting. Just after 12:15 AM (Pacific daylight savings time), while walking through the crowded kitchen, Kennedy paused and turned to his left to shake hands with a busboy. At that moment, a Jordanian immigrant, Sirhan Sirhan, stepped in front of Kennedy and fired 8 shots with a .22-caliber Iver Johnson Cadet revolver. Three of the bullets struck the senator. Five other individuals standing behind Kennedy suffered nonfatal gunshot injuries. ${ }^{27,38}$

\section{Immediate Care of Kennedy Following the Shooting}

Kennedy immediately fell to the floor. He was semiconscious during the approximately 17 minutes he lay on the kitchen floor. ${ }^{15}$ The senator's campaign manager, Stephen

ABBREVIATIONS CT = computed tomography; GCS = Glasgow Coma Scale; ICU = intensive care unit; LAPD = Los Angeles Police Department.

SUBMITTED February 11, 2018. ACCEPTED April 26, 2018.

INCLUDE WHEN CITING Published online June 19, 2018; DOI: 10.3171/2018.4.JNS18294. 
Edward Smith, announced that a doctor was needed urgently. Five physicians, who had been in the ballroom, responded. These included Stanley Abo, a radiologist; Richard O. Dean, an internist and relative of Reverend Martin Luther King Jr.; Ross M. Miller Jr., a trauma surgeon; ${ }^{8}$ and George Lambert, a physician with American Airlines. ${ }^{40}$ The fifth physician, Marvin Esher, noted that the senator had shallow breathing with a heart rate of 50-60 beats per minute. Kennedy's left eye was closed; his right eye was open and deviated to the right. He was still able to move all four extremities. ${ }^{26}$ Dr. Abo noted that Kennedy was losing consciousness and examined the senator's head wound. A small blood clot had formed at the site of the bullet hole in the right posterior auricular region. Abo assumed that blood was accumulating in Kennedy's head and inserted his finger into the hole to disrupt the clot. With that action, the clot dislodged, blood flowed freely from the bullet hole, and Kennedy's consciousness briefly improved. ${ }^{22}$ This description is eerily similar to the initial events surrounding Abraham Lincoln's assassination. After John Wilkes Booth had shot Lincoln, Dr. Charles A. Leale was the first physician to treat the president. When Leale examined the president, Lincoln's respiratory rate was very irregular and slow. Dr. Leale inserted his finger into the entrance wound behind Lincoln's left ear, which disrupted a clot, allowing blood to drain and pressure within the skull to decrease. Similar to what was seen with Senator Kennedy, this action resulted in an improvement in Lincoln's respiratory effort; however, it did not change the ultimate outcome for Lincoln any more than it did for Kennedy. ${ }^{30}$

Approximately 2 minutes after the shooting, at 12:17 $\mathrm{AM}$, the switchboard operator at the Ambassador Hotel phoned the Los Angeles Police Department (LAPD) headquarters to report that Senator Kennedy had been shot. The operator did not know the type or severity of the injury. LAPD contacted Central Receiving Hospital and asked for an ambulance to be dispatched to the hotel. ${ }^{26}$ The 40-bed Central Receiving Hospital was 2.1 miles from the hotel and was the main dispatch site for ambulance services in central Los Angeles. The ambulance attendants were surprised when they found Kennedy lying on the floor of the kitchen with blood around his head..$^{34}$ They loaded the senator onto a stretcher at 12:32 AM and took him down the freight elevator to the loading dock, where they had parked the ambulance..$^{15}$ If the dispatcher had known the injury was a gunshot to the head, the ambulance driver would likely have been instructed to bypass the smaller hospital and go directly to the nearby 400bed Good Samaritan Hospital. The ambulance arrived at Central Receiving Hospital at approximately 12:45 AM, 30 minutes after the shooting. ${ }^{26}$

\section{Arrival at Central Receiving Hospital With Kennedy In Extremis}

When the senator arrived at Central Receiving Hospital, he was unconscious with a fixed gaze; he was not breathing, his pulse was hard to detect, and his blood pressure could not be measured. ${ }^{26}$ Kennedy was immediately cared for by Dr. V. Faustin Bazilauskas. A cutdown at the ankle provided intravenous access. ${ }^{26}$ The medical team inserted an oral airway, placed a respirator mask to provide positive pressure ventilation, and then began chest compressions, which continued for 10 minutes. Kennedy received adrenalin and intravenous boluses of dextran and albumin. His blood pressure returned to 150/90 mm Hg (systolic/ diastolic) and some respiratory effort was seen. ${ }^{9,22}$ Dr. Bazilauskas and a surgeon, Dr. Albert Holt, quickly realized that they were not able to offer the care needed for the severity of the head injury. Dr. Holt knew the neurosurgeons at the Good Samaritan Hospital and called the senior surgeon, Dr. Henry Cuneo, to arrange transfer. Since he was uncertain whether the other bullet wounds in Kennedy's right posterior chest had penetrated the thorax, Dr. Holt also called Dr. Bert Meyers, the chief of thoracic surgery at Good Samaritan. ${ }^{22}$ Dr. Holt accompanied the senator in the ambulance so that he could directly communicate with the neurosurgery and thoracic surgery teams. ${ }^{22}$

\section{Craniotomy at Good Samaritan Hospital}

The distance from Central Receiving Hospital to Good Samaritan Hospital was about 0.4 miles, or 2 city blocks. Most of the press and Kennedy supporters who had arrived at Central Receiving Hospital simply walked over to Good Samaritan Hospital when they saw Kennedy had been moved. ${ }^{17}$

Kennedy arrived at the fifth-floor intensive care unit (ICU) at approximately $1 \mathrm{Am}$; he was initially treated by 2 surgical residents, Drs. Paul A. Ironside and Hubert Humble..$^{22}$ A tracheostomy tube was placed just after his arrival. The senator was fully disrobed, and the other 2 injuries were inspected. There was a gunshot wound on the right side of his back. Radiographic findings suggested that the bullet was lodged in the subcutaneous tissue of the neck. This injury was not considered life threatening. In addition, there were wounds in the right axilla and right shoulder, but no corresponding bullets were found on $\mathrm{x}$ ray films. The chest surgeons determined that no bullets had entered the thorax. Kennedy had significant hypertension (systolic pressure $280 \mathrm{~mm} \mathrm{Hg}$ ) when he arrived at the Good Samaritan ICU; once the tracheostomy had been completed, his blood pressure improved. ${ }^{22}$ At the scene of the shooting, Kennedy had displayed diminished motor activity on the left side of his body. By the time he was evaluated at Good Samaritan Hospital, however, he had lost all motor activity in response to pain. Whole blood was administered to replace the continued bleeding from the bullet wound in the mastoid region. ${ }^{10}$

Kennedy was transferred to the operating room on the ninth floor of Good Samaritan at 2:45 AM, 2 hours and 30 minutes after the shooting. As the operative team began to transport Kennedy, they encountered members of the press and well-wishers who had congregated outside the ICU and in the waiting room, hallways, and lobby near the elevators. Because of the crowd, the hospital staff could not transfer Kennedy directly to the ninth-floor operating suite as planned. Instead, they moved the senator's stretcher to a back elevator. This elevator did not ascend all the way to the ninth floor, but instead went up to the sixth floor, where there was no crowd. After the stretcher 
reached the sixth floor, it was guided back to the main elevators and moved to the ninth floor. ${ }^{22}$

The operation started at 3:10 AM. The senior neurosurgeon was Dr. Henry Cuneo, an associate clinical professor of neurosurgery at the University of Southern California. Dr. Cuneo had graduated from Baylor University School of Medicine in 1937 and had served as a lieutenant colonel in the Navy Medical Corps from 1944 to 1946. Before coming to Los Angeles in 1961, he had also served as chief of neurosurgery at naval hospitals in Great Lakes, Illinois; New Orleans; and Parris Island, South Carolina. Other members of the surgical team were Dr. Maxwell Andler of the University of California at Los Angeles Medical School and Dr. Nat Downes Reid of the University of Southern California Medical School. ${ }^{16}$

Preoperative radiographs demonstrated significant bone fragments within the brain parenchyma. As was the standard of the day, the surgeons believed that they needed to remove as many bone and bullet fragments as possible in addition to obtaining control of intracranial bleeding. The operation took over 3 hours and 45 minutes to complete. After the surgeons had created several burr holes near the bullet entrance wound, a 5-cm craniotomy flap was elevated. This resulted in the return of the senator's spontaneous respirations. During the operation, portions of the occipital lobe and right cerebellum were debrided of devitalized tissue. Bleeding from the petrous sinus was eventually controlled. Intraoperatively, Kennedy was given dexamethasone and mannitol to help control cerebral edema. At the end of the operation, he was placed on a cooling blanket. Kennedy regained some motor activity on the right side of his body, as shown by his response to a pinprick, but there was still a poor response to painful stimulation along his entire left side..$^{10,24}$

\section{Postoperative Course}

During Kennedy's brief postoperative course, several neurosurgeons from around the country were consulted. Dr. Cuneo called Dr. J. Lawrence Pool to discuss the case. Dr. Pool was chief of neurosurgery at the Neurological Institute of New York. He had completed his medical degree at the University of Pennsylvania and trained in neurosurgery at the Neurological Institute of New York. ${ }^{33}$ During his conversation with Dr. Cuneo, Dr. Pool stated that given the damage, even if Kennedy could survive the initial insult, his neurological outcome would be tragic.

Pierre Salinger, one of the candidate's campaign managers and a friend of the Kennedy family, called Dr. James L. Poppen, a neurosurgeon at Boston's Lahey Clinic, at 4 AM on June 5, while the senator was in surgery. Salinger asked if Poppen could fly immediately to Los Angeles and consult on the case. Dr. Poppen, who had attended Rush Medical School in Chicago and joined the Lahey Clinic in 1933, where he served as its chief of neurosurgery from 1957 to $1964,{ }^{5}$ maintained a long relationship with the Kennedys and had treated other members of the family. Vice President Hubert H. Humphrey was contacted and arranged for the Air Force to transport Dr. Poppen to Los Angeles. Dr. Poppen arrived just before 10 AM on June 5, approximately 4 hours after the operation had been com- pleted. When he examined Kennedy, he thought the prognosis was grave. He continued to consult with Dr. Cuneo and his team and acted as a liaison to the Kennedy family.

In the initial postoperative period, Kennedy was relatively stable. By 6 PM on June 5, approximately 12 hours after surgery, his condition began to deteriorate. Presumably, Kennedy's intracerebral pressure had started to rise, because his electroencephalogram readings became flat and he lost his respiratory effort. Kennedy never regained consciousness. He was pronounced dead at 1:44 AM (Pacific daylight savings time) on June $6,1968 .^{22}$

\section{Autopsy Findings}

Famed Los Angeles County Chief Medical Examiner Thomas Noguchi conducted the autopsy of Robert F. Kennedy. Dr. Noguchi served in the chief medical examiner position from 1967 to 1982 and conducted autopsies of many famous individuals, including Marilyn Monroe, Sharon Tate, Natalie Wood, Janice Joplin, and John Belushi.

The autopsy began on June 6. It has been called "the perfect autopsy" for its attention to detail. ${ }^{7}$ At its conclusion, the autopsy documented 3 gunshot injuries. One bullet entered the right axilla posteriorly and exited near the right clavicle. The second bullet entered the back on the right side, lodging at the base of the neck in the subcutaneous space. Neither of these injuries caused life-threatening harm. ${ }^{28}$ The lethal injury to the right posterior auricular region had associated powder burns on the skin, and therefore Noguchi stated that the gun was within 3 inches when the shooting occurred. Examination of the intracranial contents showed extensive injury to the right cerebellum and right occipital cortex. There were multiple bone and bullet fragments scattered across the brain tissue, and evidence of epidural, subdural, and subarachnoid hemorrhage. There was also evidence of brainstem herniation due to cerebral edema. Damage to the brainstem was likely due to this herniation and not to direct trauma. Both the right middle cerebral artery and the petrous sinus were injured by bullet and bone fragments and were the predominant source of the bleeding (see Fig. 1). After physical examination of the body, Noguchi evaluated the gun, bullets, Kennedy's clothes, and ballistics tests. The discrepancy between eyewitness reports that Sirhan came no closer than 12 to 18 inches from Kennedy when the shooting occurred and the Noguchi report, which stated that the gun was within 3 inches of the right ear at the time of the shooting, was not highlighted in the autopsy report. Noguchi, in his later writings, makes it clear that his report did not imply that Sirhan was the lone shooter, leaving the door open for conspiracy theorists. ${ }^{29}$

\section{Analysis of Kennedy's Medical Care}

Kennedy suffered 3 gunshot wounds. Two of these injuries were relatively trivial. The injuries sustained by Kennedy occurred just after 12:15 AM, and he was moved to Central Receiving Hospital at 12:32 AM. This delay is commonplace and likely could not have been improved. Unfortunately, valuable time was lost with the stop at Central Receiving Hospital. Both Central Receiving Hospi- 

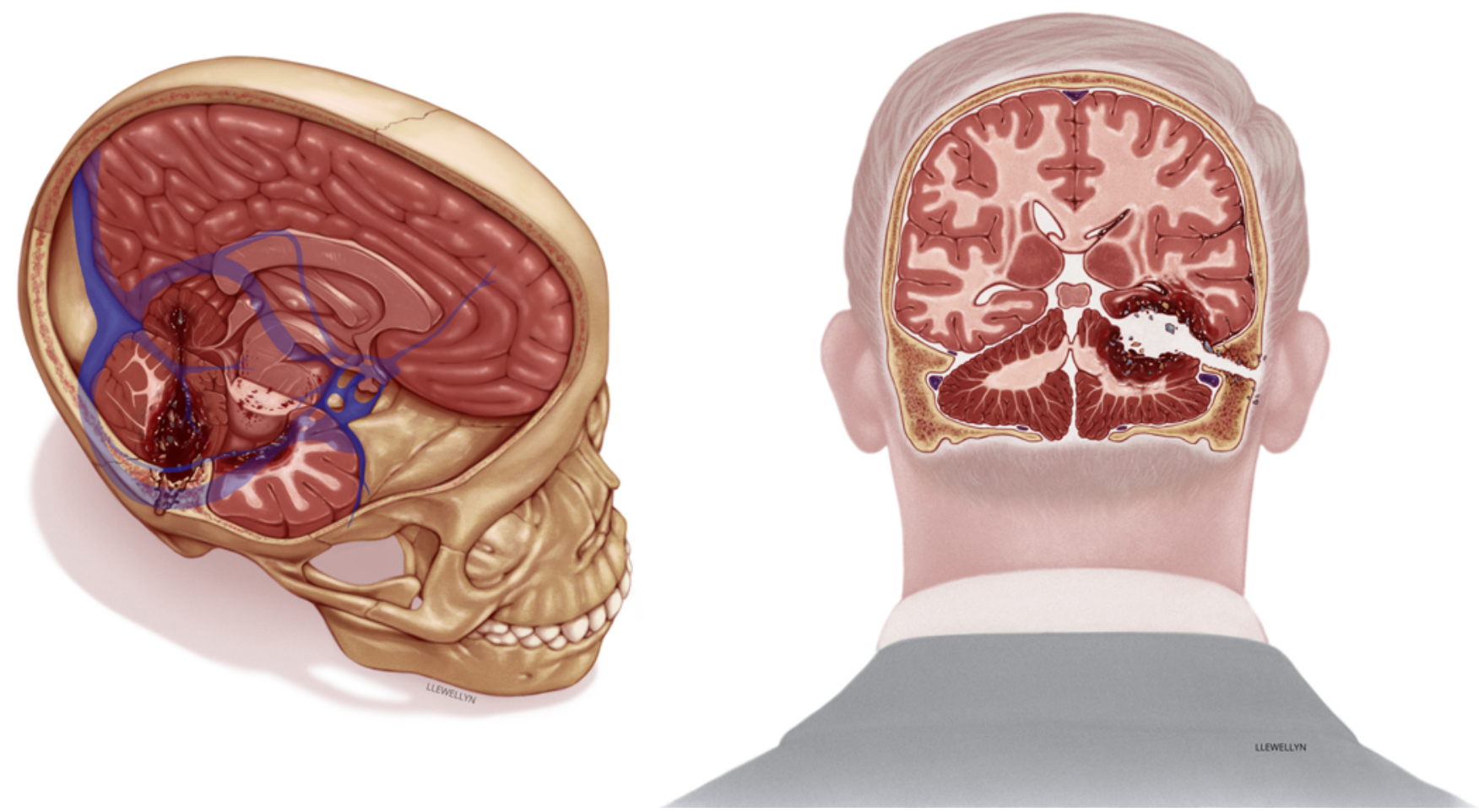

FIG. 1. Artist's representation of Senator Kennedy's injuries (lateral [left] and posterior [right] views). This representation was created based on data from the autopsy report and testimony, as no imaging studies are available for review. Illustrator: Megan Llewellyn, MSMI; copyright Duke University, with permission under a CC BY-ND 4.0 license (https://creativecommons.org/licenses/ by-nd/4.0/).

tal and Good Samaritan Hospital were approximately 2 miles from the Ambassador Hotel. If the senator had been transported directly to the larger hospital, approximately 45 minutes would have been saved. The resuscitation procedure initiated at Central Receiving Hospital could have occurred at Good Samaritan Hospital.

The Brain Trauma Foundation has compiled guidelines regarding the care of persons with severe traumatic brain injury, ${ }^{3}$ including those injured via gunshots to the head..$^{32}$ These guidelines have shaped much of the contemporary management of cranial gunshot injuries. Following initial resuscitation, care of the cranial gunshot victim focuses on diagnostic imaging, surgical debridement, and management of cerebral edema to prevent elevated intracranial pressure.

Like many other aspects of trauma care, the management of cranial gunshot wounds has evolved from lessons learned from combat situations. In 1918, Harvey Cushing published his observations on penetrating head trauma during World War I. ${ }^{6}$ Dr. Cushing proposed a grading scale based on the extent of projectile penetration and whether the ventricular system was injured. The group of patients in Dr. Cushing's collection whose injuries most closely mirrored those of Senator Kennedy had a 54.3\% mortality rate. This high rate of mortality unfortunately holds true in modern series of cranial gunshot wounds. ${ }^{14}$ Dr. Cushing's work is key to the discussion of penetrating head trauma, because it began to differentiate patterns of injury that portend a worse prognosis. Several more modern studies have confirmed and refined Dr. Cushing's original observation that prognosis is linked to the pattern of cerebral injury. ${ }^{13,20,21,25,35}$ Patterns shown to be associated with higher rates of mortality include those involving the brainstem, the bilateral thalami, or the posterior fossa, as well as those traversing the ventricle. . $^{13,14}$

By the time Senator Kennedy was evaluated at Good Samaritan Hospital, where he subsequently underwent an emergency craniotomy, he was reported to have no motor function. We do not know with certainty whether his eyes opened to verbal or even painful cues, and thus we do not know his exact Glasgow Coma Scale (GCS) score. We do, however, know that his GCS verbal subscore was 1 and the motor subscore was 1 . This would give a GCS score range of $3 \mathrm{~T}$ to $6 \mathrm{~T}$. This finding on a presenting neurological examination predicts a poor prognosis and would prompt many neurosurgeons to make the controversial decision not to offer aggressive surgical intervention..$^{13}$ During the craniotomy performed on Kennedy, the neurosurgeons noted extensive damage to the cerebellum, occipital lobe, and petrosal sinus.

It is the authors' opinion that Senator Kennedy received aggressive and appropriate care in line with the standard of the day. The senator was transported to the operating room for decompression and then monitored in an ICU. Attempts were made to treat his cerebral edema with mannitol and glucocorticoids. The senator was also placed on a cooling blanket and monitored with electroencephalography. As we face the 50th anniversary of Senator Kenne- 
dy's assassination, we can comment on several differences in medical practice as it is today. These differences more largely reflect advances in neuroimaging and neurocritical care than the technical aspects of surgical treatment. If the senator were to be shot in 2018, rather than in 1968, following initial stabilization he would most likely undergo computed tomography (CT) of his head,,${ }^{13,18}$ without addition of contrast material, as well as CT arteriography and venography. ${ }^{31}$ These recommendations are based on level III evidence. CT was not available until the 1970s and was thus not an option for physicians caring for the senator. ${ }^{2}$ As far as we can tell from the available data, if the injuries were to be sustained today, Senator Kennedy would undergo surgery similar to the craniotomy performed in 1968. The focus of surgery would be to remove devitalized tissue, provide relief of intracranial pressure, and control hemorrhage.

The modern neurosurgeon's task would most likely be made easier by use of the operating microscope. We do not know for sure whether the microscope was available to the senator's neurosurgical team, but the first reports of neurosurgeons using a microscope in surgery were published in the 1950s, making it very possible that the surgical team did not have access to this relatively new advance. ${ }^{23}$ During surgery, Senator Kennedy received mannitol and dexamethasone to control cerebral edema. This was standard at the time the senator was treated. Mannitol remains a mainstay of therapy in the treatment of posttraumatic cerebral edema, ${ }^{3}$ but recent evidence argues against the use of steroids in the setting of nontumoral cerebral edema. ${ }^{9}$ This is class I evidence. The senator was placed on a cooling blanket, we presume to prevent fever and assist with management of cerebral edema (although it is not specified). Therapeutic hypothermia following traumatic brain injury is a topic of significant interest, but there is enough clinical equipoise to justify fever prevention both then and now. ${ }^{1}$ Last, in a patient suffering from a cranial gunshot wound, who required intubation like the senator, one would likely place a device to directly monitor intracranial pressure. While there is some debate about this practice, ${ }^{4}$ it is largely considered standard of care in patients with a GCS score consistently less than $8 .^{3}$ This type of monitoring commonly takes the form of an external ventricular drain. These drains were not commonly used in the setting of trauma until the $1980 \mathrm{~s} \cdot{ }^{36}$ If the injury occurred today, the senator would likely receive antiepileptic medications, as we now know they can prevent seizures in the short term following trauma. ${ }^{37}$

\section{Aftermath}

Hubert Humphrey went on to win the Democratic nomination in a contentious convention in Chicago. Richard Nixon temporarily recovered his political career by successfully securing his party's presidential nomination at the Republican National Convention in Miami Beach in August. Nixon won the election in November by a close margin but recast American history with his ultimate resignation following the Watergate scandal.

Similar to the assassination of his brother, President John F. Kennedy, the assassination of Robert Kennedy is surrounded in conspiracy theory. This is despite the fact that many people witnessed the shooting. Much has been made of the fact that the assassin approached Kennedy from the front, but the gunshot wounds were in the back. Several witnesses documented that Kennedy's head was turned to his left as he was shot, which explains the trajectory of the bullets. In addition, witnesses claim that Sirhan came no closer than a foot from Kennedy when the shooting occurred, but the autopsy report estimates that the gun was within inches of the skin based on the presence of gunpowder in the wound. The same witnesses did not see another shooter. Despite concern over the trajectory of the bullet and controversy about gunpowder on the skin, there was never clear evidence of conspiracy and Sirhan was ruled the lone gunman.

Before the shooting, Sirhan Sirhan kept a diary in which he claimed, "Kennedy must die." The reason given was related to Kennedy's support of Israel. Sirhan was a Christian Jordanian of Palestinian descent. Sirhan stood trial and was convicted of the murder of Robert F. Kennedy. He was sentenced to death, but his sentence was later commuted to life in prison at a correctional facility in California.

\section{References}

1. Andrews PJD, Sinclair HL, Rodriguez A, Harris BA, Battison CG, Rhodes JKJ, et al: Hypothermia for intracranial hypertension after traumatic brain injury. $\mathbf{N}$ Engl J Med 373:2403-2412, 2015

2. Brenner DJ, Hall EJ: Computed tomography-an increasing source of radiation exposure. N Engl J Med 357:2277-2284, 2007

3. Carney N, Totten AM, O'Reilly C, Ullman JS, Hawryluk GWJ, Bell MJ, et al: Guidelines for the management of severe traumatic brain injury, fourth edition. Neurosurgery 80:6-15, 2017

4. Chesnut RM, Temkin N, Carney N, Dikmen S, Rondina C, Videtta W, et al: A trial of intracranial-pressure monitoring in traumatic brain injury. N Engl J Med 367:2471-2481, 2012

5. Chicago Tribune: How RFK died 7 hrs. before it was told. Knew he could not live: doctor. Chicago Tribune. June 8, 1968; 3

6. Cushing H: Notes on penetrating wounds of the brain. BMJ 1:221-226, 1918

7. DiEugenio J, Pease L: The Assassinations: Probe Magazine on JFK, MLK, RFK and Malcolm X. Port Townsend, WA: Feral House, 2003

8. Ebony Magazine: Robert F. Kennedy and the Negro. Ebony Magazine 23:29-46, 1968

9. Edwards P, Arango M, Balica L, Cottingham R, El-Sayed H, Farrell B, et al: Final results of MRC CRASH, a randomised placebo-controlled trial of intravenous corticosteroid in adults with head injury-outcomes at 6 months. Lancet 365:1957-1959, 2005

10. Federal Bureau of Investigation: Robert F. Kennedy Assassination. (https://archive.org/stream/ RFKAssassination_201510/RFK-LA-56-156\%20VOL.01SER.001-0250\#page/n0/mode/2up) [Accessed May 30, 2018]

11. Frankel M: It all adds up for Richard Nixon. New York Times. August 11, 1968; 1

12. Gallup G: Humphrey favored by local Democratic leaders. Los Angeles Times. August 29, 1968; 6

13. Grahm TW, Williams FC Jr, Harrington T, Spetzler RF: Civilian gunshot wounds to the head: a prospective study. Neurosurgery 27:696-700, 1990 
14. Gressot LV, Chamoun RB, Patel AJ, Valadka AB, Suki D, Robertson CS, et al: Predictors of outcome in civilians with gunshot wounds to the head upon presentation. J Neurosurg 121:645-652, 2014

15. Hamill P: June 5, 1968: The last hours of RFK. New York Magazine. May 18, 2008 (http://nymag.com/news/ politics/47041/) [Accessed May 29, 2018].

16. Harold Weisberg Archive: Sketches of surgeons on team, in Hood College Harold Weisberg Archive. (http:// jfk.hood.edu/Collection/White\%20Materials/White\%20 Assassination\%20Clippings\%20Folders/Kennedy $\% 20$ Family\%20Folders/Kennedy\%20Robert\%20F/RFK\%200381. pdf) [Accessed May 31, 2018]

17. Healy P: Robert F. Kennedy's assassination: from ballroom to the hospital. Daily News. June 6, 1968 (http://www. nydailynews.com/news/national/reporter-coversrfk-assassination-article-1.2237677) [Accessed May 30, 2018]

18. Helling TS, McNabney WK, Whittaker CK, Schultz CC, Watkins M: The role of early surgical intervention in civilian gunshot wounds to the head. J Trauma 32:398-400, 1992

19. Houston P: Wife was reassured by heartbeat sounds. Los Angeles Times. June 6, 1968; 1

20. Hubschmann O, Shapiro K, Baden M, Shulman K: Craniocerebral gunshot injuries in civilian practice-prognostic criteria and surgical management: experience with 82 cases. J Trauma 19:6-12, 1979

21. Joseph B, Aziz H, Pandit V, Kulvatunyou N, Hashmi A, Tang A, et al: A three-year prospective study of repeat head computed tomography in patients with traumatic brain injury. J Am Coll Surg 219:45-51, 2014

22. Kaiser RB: "R.F.K. Must Die!" Chasing the Mystery of the Robert Kennedy Assassination. New York: The Overlook Press, 2008

23. Kriss TC, Kriss VM: History of the operating microscope: from magnifying glass to microneurosurgery. Neurosurgery 42:899-908, 1998

24. Los Angeles Times: All-out surgical effort to save Kennedy told. Los Angeles Times. June 10, 1968

25. Martins RS, Siqueira MG, Santos MTS, Zanon-Collange N, Moraes OJS: Prognostic factors and treatment of penetrating gunshot wounds to the head. Surg Neurol 60:98-104, 2003

26. Moldea DE: The Killing of Robert F. Kennedy: An Investigation of Motive, Means, and Opportunity. New York: WW Norton \& Company, 2006

27. Newsweek Staff: Robert Kennedy shot, killed in Los Angeles. Newsweek. June 6, 1968. (http://www.newsweek.com/ robert-kennedy-shot-killed-los-angeles-207078) [Accessed May 29, 2018]

28. Noguchi TT, Holloway JE, Lu AT: Robert F. Kennedy Autopsy: Second Draft. (http://www.autopsyfiles.org/reports/ Other/kennedy,\%20robert_report.pdf) [Accessed May 30, 2018]
29. Noguchi TT, DiMona J: Coroner. New York: Open Road Media, 2014

30. Papaioannou HI, Stowell D: Dr. Charles A. Leale's report on the assassination of Abraham Lincoln. J Abraham Lincoln Assoc 34:40-53, 2013

31. Pruitt BA Jr (ed): Neuroimaging in the management of penetrating brain injury. J Trauma 51 (2 Suppl):S7-S11, 2001

32. Pruitt BA Jr (ed): Surgical management of penetrating brain injury. J Trauma 51 (2 Suppl):S16-S25, 2001

33. Quest DO: James Lawrence Pool. Neurosurgery 55:942, 2004

34. Rasmussen C: A pioneering public hospital checks out. Los Angeles Times. October 2, 2005 (http://articles.latimes. com/2005/oct/02/local/me-then2) [Accessed May 29, 2018]

35. Shaffrey ME, Polin RS, Phillips CD, Germanson T, Shaffrey CI, Jane JA: Classification of civilian craniocerebral gunshot wounds: a multivariate analysis predictive of mortality. $\mathbf{J}$ Neurotrauma 9 (Suppl 1):S279-S285, 1992

36. Srinivasan VM, O'Neill BR, Jho D, Whiting DM, Oh MY: The history of external ventricular drainage. J Neurosurg 120:228-236, 2014

37. Temkin NR, Dikmen SS, Wilensky AJ, Keihm J, Chabal S, Winn HR: A randomized, double-blind study of phenytoin for the prevention of post-traumatic seizures. N Engl J Med 323:497-502, 1990

38. Turner W: The shooting: a victory celebration that ended with shots, screams, and curses. New York Times. June 6, 1968; 21

39. United Press International: Police chief says Kennedy turned down security aid. New York Times. June 6, 1968; 20

40. Weaver W Jr: Kennedy shot and gravely wounded after winning California primary. New York Times. June 5, 1968; 1

41. Young R: LBJ: won't run. Stuns nation at end of TV, radio speech. Chicago Tribune. April 1, 1968; 1

\section{Disclosures}

The authors report no conflict of interest concerning the materials or methods used in this study or the findings specified in this paper.

\section{Author Contributions}

Conception and design: all authors. Drafting the article: Pappas, Komisarow, Lad. Critically revising the article: Pappas, Komisarow, Lad. Reviewed submitted version of manuscript: all authors. Administrative/technical/material support: Llewellyn.

\section{Correspondence}

Theodore Pappas: Duke University School of Medicine, Durham, NC.theodore.pappas@duke.edu. 